\title{
A multimethod paleointensity approach applied to the historical Xitle lava flows (Central Mexico): towards the accurate paleointensity determination
}

\author{
Juan Morales ${ }^{1 *} \mathbb{0}$, Nayeli Pérez-Rodríguez ${ }^{2} \mathbb{0}$, Avto Goguitchaichvili ${ }^{1}$ and Miguel Cervantes-Solano ${ }^{3}$
}

\begin{abstract}

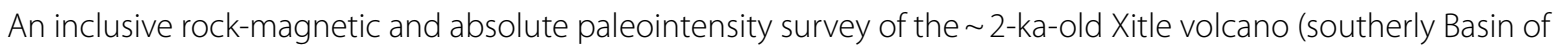
Mexico) was undertaken to assess the faithfulness of the paleomagnetic log carried by fresh, widely exposed and well-preserved lava flows. Paleomagnetic samples from six lava flows were subjected to paleointensity analysis with a multi-method approach: the Thellier-Coe, IZZI, and multi-specimen methods. Overall mean flow PI values from flows 4-6 obtained by the Thellier-type methods used yielded $68.4 \mu \mathrm{T}(\sigma= \pm 5.6 \mu \mathrm{T}), 63.9 \mu \mathrm{T}(\sigma= \pm 5.8 \mu \mathrm{T})$ and $61.5 \mu \mathrm{T}$ $(\sigma= \pm 4.3 \mu \mathrm{T})$ for the TC, IZZI, and IZZI with CR correction methods, respectively. Although multi-specimen paleointensity results were, in general, lower than that obtained with the other methods for the same flows, that for Flow 5 $(61.8 \mu \mathrm{T})$ was very similar to those obtained with the Thellier-type methods. Based on the results obtained, this lava flows sequence could correspond to two eruptive periods; one related with the Xitle volcano (flows 3-6), and another older (flows 1 and 2). The combined archeomagnetic dating of the different flows reinforces this hypothesis, as well as the multi-modal distribution for the age of the Xitle, proposed two decades ago. The application of stricter acceptance criteria and consideration of cooling-rate correction could slightly reduce the scattered observations. The multimethod approach employed under this study, combined with detailed rock-magnetic experiments, may definitively increase the accuracy of paleointensity determinations.
\end{abstract}

Keywords: Xitle volcano, Paleointensity, Methodology, Mexico

\section{Introduction}

The Xitle volcano belongs to the Chichinautzin Quaternary volcanic field. It is located south of the Valley of Mexico (Herrero-Bervera et al. 1986; Urrutia-Fucugauchi and Martin-del Pozzo 1993). It is a monogenetic cone whose lavas overlay an area of approximately $80 \mathrm{~km}^{2}$ in which seven flow-units are identified (Fig. 1; DelgadoGranados et al. 1998). The largest flow to the north is more than $13 \mathrm{~km}$ long, encompassing an area of $70 \mathrm{~km}^{2}$

\footnotetext{
*Correspondence: jmorales@geofisica.unam.mx

${ }^{1}$ Laboratorio Interinstitucional de Magnetismo Natural (LIMNA) y Servicio Arqueomagnético Nacional (SAN), Instituto de Geofísica, UNAM, Unidad Michoacán, Morelia, Mexico

Full list of author information is available at the end of the article
}

(Martin-del Pozzo et al. 1997; Delgado-Granados et al. 1998) and covering the first urban settlements of the Valley of Mexico (Heizer and Bennyhoff 1958) - the archeological center of Cuicuilco.

Being one of the youngest volcanoes, charred material (charcoal from pottery level below lava) by its eruption was used during the development of the innovative radiocarbon method for dating organic materials (Arnold and Libby 1951; Libby 1955), obtaining a date of $2422 \pm 250$ years BP. After this, more than 30 further studies have been reported, yielding a breadth age interval for the Xitle's eruption. Through a comprehensive review of the available radiometric dates, Urrutia-Fucugauchi (1996) identified three apparent clusters roughly 


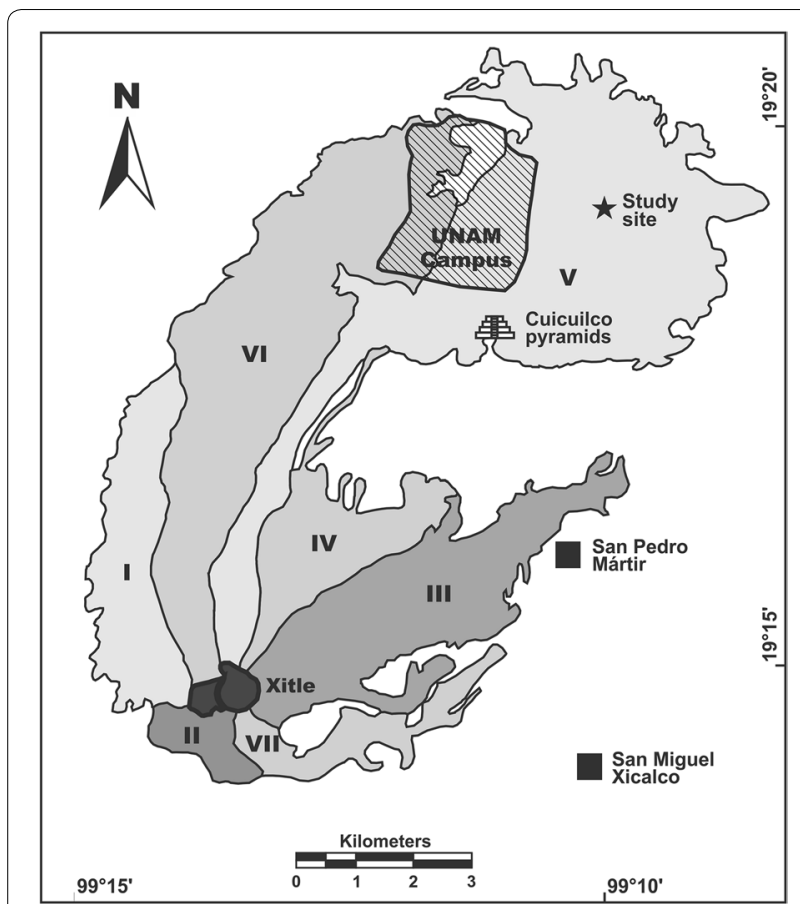

Fig. 1 Location map of Xitle volcano and the spatial distribution of its different lava flows (modified from Delgado-Granados et al. 1998)

around 4000, 2375, and 2000 years BP. The older cluster is mainly associated with the early archeological occupation Tlalpan stages (Fergusson and Libby 1963), while the other two to the age for the Xitle eruption, respectively. Moreover, an age of 1670 years BP was proposed (Siebe 2000).

Likewise, its different lavas have aided to appraise the reliableness of the paleomagnetic log carried by fresh, widely exposed and well-preserved lava flows (Urrutia-Fucugauchi 1996). In the case of paleointensity (PI) determinations, it seems to be also a matter of controversy. Pioneer estimations of Nagata et al. (1965a) yielded a mean PI value of $56.11 \pm 5.89 \mu \mathrm{T}(n=8)$, while those of González-Huesca (1992), Morales-Contreras (1995) and Urrutia-Fucugauchi (1996) yielded mean PI values of $66.83 \pm 10.09 \mu \mathrm{T}(n=6), 59.2 \pm 11.0(n=9)$ and $60.04 \pm 9.62 \mu \mathrm{T}(n=6)$, respectively. It is worth mentioning that all these studies were carried out on sites from different flows of the Xitle volcano.

Moreover, variations in the PI values are observed across vertical sections within a single flow (e.g., UrrutiaFucugauchi 1996; Böhnel et al. 1997; Alva-Valdivia 2005; Morales et al. 2006). Given its monogenetic nature and considering that recent historical eruptions of similar volcanoes in the Mexican volcanic belt point to brief activity periods, around a decade or so (e.g., Paricutin 1943-1953 or the 1759-1774 Jorullo eruptions; Bullard 1976) no such PI differences should be obtained. Attempts to correlate the observed PI variation to rock-magnetic properties, different oxidation states, etc., have not been able to account for these inter-flow variations.

The refinement of PI methods and the proposal of stricter acceptance criteria have arisen with time, as well as new PI methods, which could contribute to a better understanding of the causes for such variations. Even more, multi-method approaches have been recently applied to the study of volcanic rock (e.g., Calvo-Rathert et al. 2016 and Calvo-Rathert et al. 2019) as an alternative criterion of reliability.

In the present study, we report the paleointensity results from six different lava effusion episodes from unit $\mathrm{V}$ of the Xitle volcano obtained with the multi-specimens and IZZI methods, considering also cooling rate correction. Likewise, we carried out a reassessment of the Thellier-Coe paleointensity results previously reported on sister samples using stricter acceptance criteria.

\section{Material and rock-magnetic results from the previous study}

The paleomagnetic sampling of lava flows was done previously and results were reported by Cervantes-Solano et al. (2019). Sampling was completed at the Ciudad Universitaria Basaltic Lava member (BCU), at the site known as La Cantera $\left(19^{\circ} 18^{\prime} 47.10^{\prime \prime} \mathrm{N}, 99^{\circ} 10^{\prime} 19.01^{\prime \prime}\right.$ W) - a quarry at the neighborhood of the UNAM facilities (Fig. 1). At this site is the most complete exposure of lava flows with a thickness of $40 \mathrm{~m}$, which corresponds to the unit V described by Delgado-Granados et al. (1998), in which seven individual lava units with thicknesses of 2 to $8 \mathrm{~m}$ each are distinguished (Fig. 2). Lava-flow sampling was realized using a hand-held water-cooled gasolinepowered drilling device with a diamond bit; all samples were oriented using a precision core orienting accessory with a magnetic compass mounted on it. Fifty-four standard paleomagnetic cores (8 to 10 samples per flow) were obtained from the exposed-interiors of six flows, which were consecutively numbered according to their stratigraphic position (i.e., 95X001AL-95X054L; L: A, B or $\mathrm{C}$, the outermost specimen, the one at the middle, or the innermost specimen), with Flow 1 the one at the bottom and Flow 6 the one at the top of the exposure. Because of its inaccessibility, Flow 7 was unable to be sampled.

Thermomagnetic curves indicate the existence of a magnetic phase during heating with Curie temperature between $520{ }^{\circ} \mathrm{C}$ and $560{ }^{\circ} \mathrm{C}$, suggesting magnetite or titanomagnetite with low titanium content as responsible for the magnetization. Cooling curves are similar to heating ones, showing a decrease in initial susceptibility less than $15 \%$, which is likely due to oxidation produced 


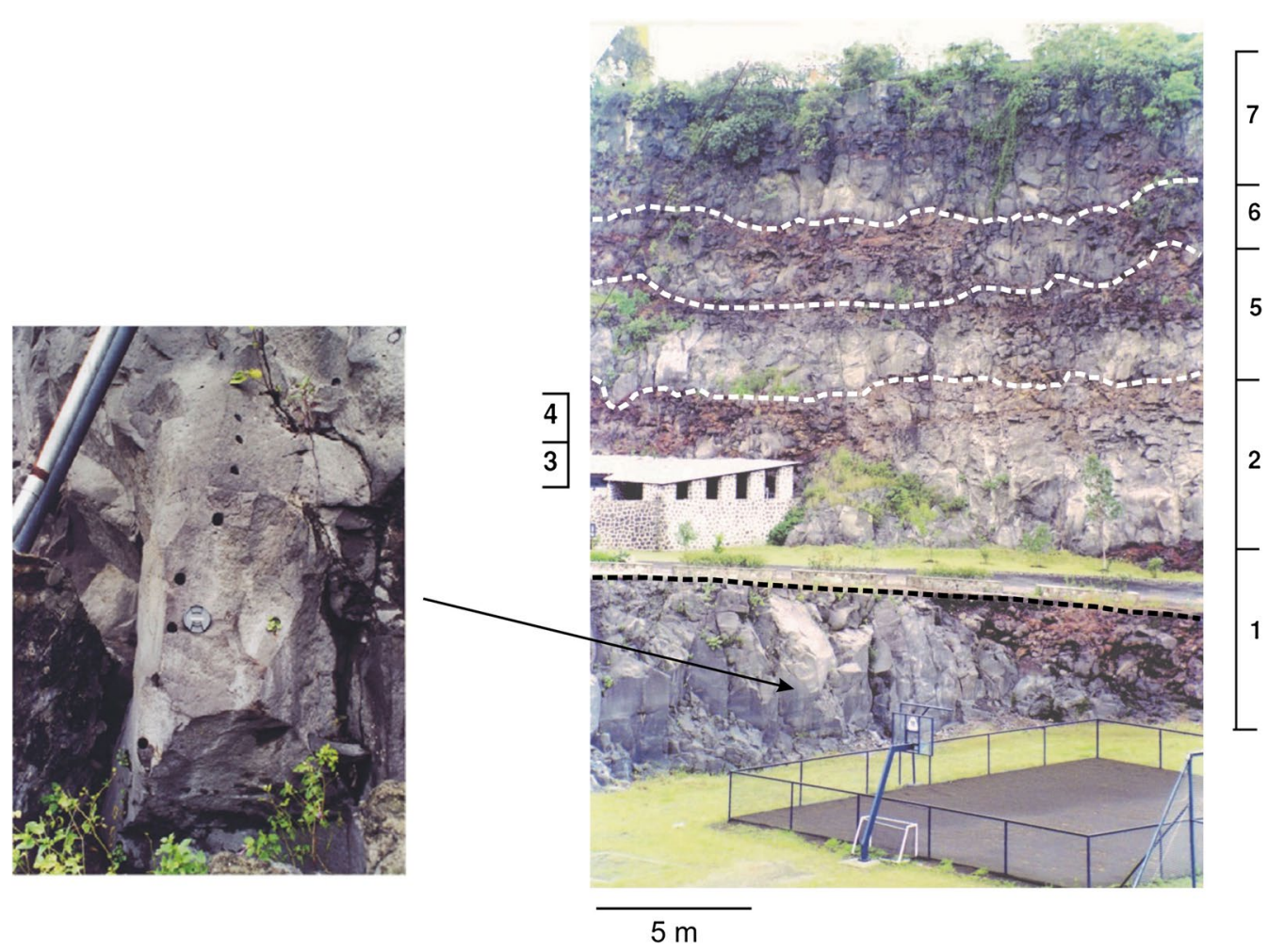

Fig. 2 Right: view of the 7 flows exposed at BCU quarry (adopted from Alva-Valdivia 2005). Left: a closer view of the paleomagnetic sampling

during heating (Fig. 3). For details of the opaque mineralogy, the reader is referred to the paper by Alva-Valdivia (2005).

In most samples studied (60\%), two magnetization components are observed, the first of which is removed during the first steps of demagnetization (fields from 5 $\mathrm{mT}$ to $10 \mathrm{mT}$ ) and represents less than $10 \%$ of the value of the total magnetization of the samples and is likely to be of viscous origin. Once this component was removed, the behavior was linear towards the origin in the orthogonal Zijderveld (1967) diagrams. Another group of samples (31\%), corresponding to flows 2 and 5, retain about 40 to $50 \%$ of the initial magnetization after having applied magnetic fields of $90 \mathrm{mT}$, however, a linear behavior towards the origin of coordinates is also observed. In the remaining $9 \%$ of samples, a single stable component was identified with a single behavior towards the origin.

Paleointensity experiments were carried out on six to seven specimens per flow (40 in total) using the Thellier double-heating method (Thellier and Thellier 1959) as modified by Coe (Coe 1967), here thereafter called Thellier-Coe (TC). Heating and cooling were done in a TD48 thermal demagnetizer from ASC Scientific. Once the specimens reached the desired temperature at each heating step, they were left for an idle of $20 \mathrm{~min}$ at that temperature so that all specimens got thermal equilibrium. Afterward, the fan was turned on permitting the samples to cool down. The laboratory field $(45.0 \pm 0.5 \mu \mathrm{T})$ remained on for infield steps during the whole heatingcooling cycle. Thirteen temperature steps were distributed between room temperature and $580{ }^{\circ} \mathrm{C}$, and pTRM checks were carried out at every third heating step, except at the last one. Natural and laboratory-induced remanent magnetizations were both measured through a JR6 dual-speed spinner magnetometer from AGICO.

\section{Experimental procedure}

The experiments were performed with material left from the former study (Cervantes-Solano et al. 2019), and the original numbers of the specimens were preserved, but for the sake of simplicity, the initial number (95) in the specimen's ID was eliminated. This enabled us to analyze sister samples, minimizing the possibility of within-flow heterogeneities, as well as the application of a multimethodological exercise on almost the same material.

\section{Rock-magnetic experiments}

Stepwise low-field susceptibility $(\kappa-T)$ curves were obtained for precise monitoring of the onset of the magneto-chemical alteration of the magnetic mineralogy. 

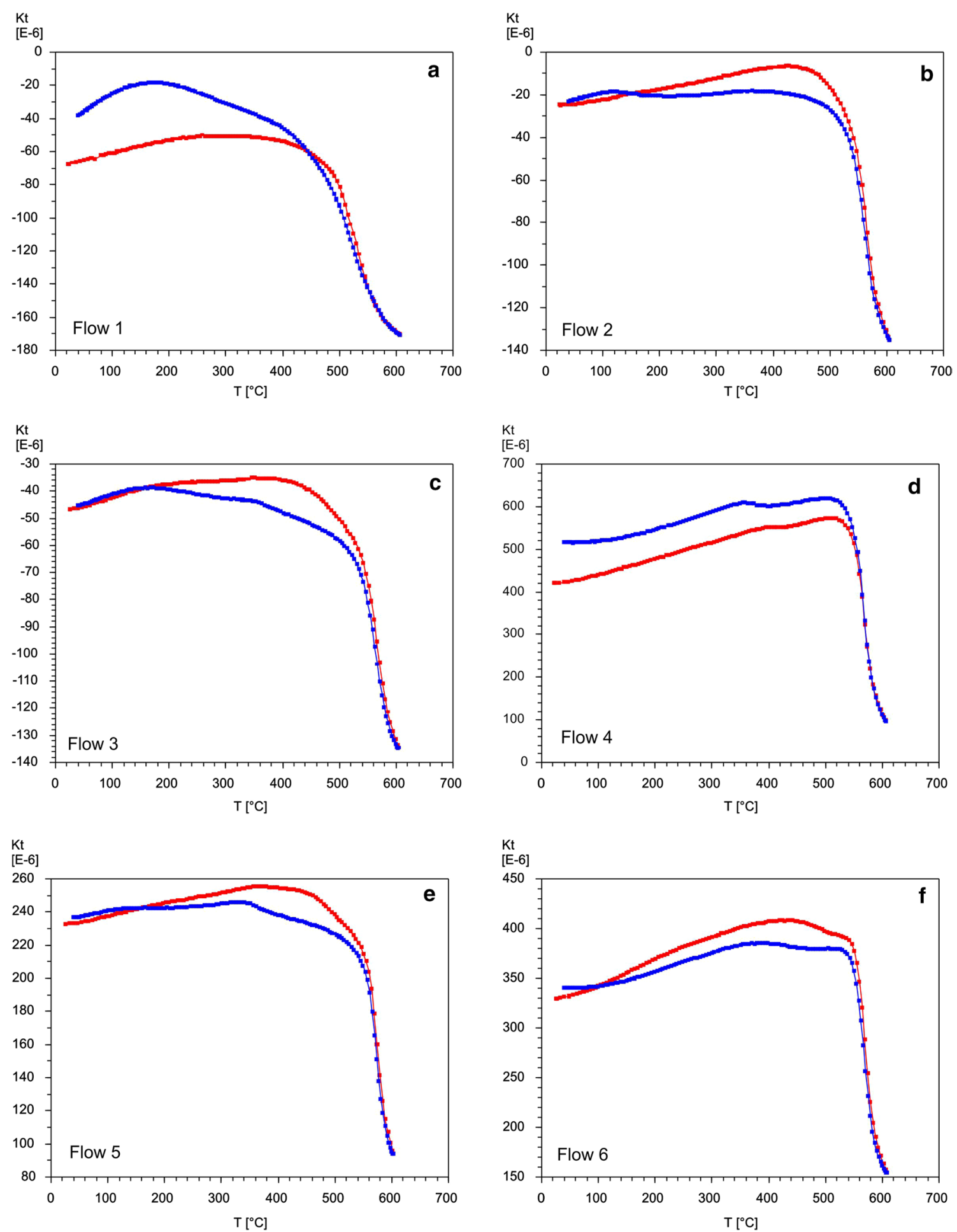

Fig. 3 Representative thermomagnetic ( $\mathrm{K}-\mathrm{T}$ ) curves for the different flows analyzed, obtained in the previous study (Cervantes-Solano et al. 2019). Curves in red correspond to the heating, while those in blue to the cooling 
This monitoring was done using an MFK1B Kappabridge from AGICO in an argon atmosphere. A four-step procedure, initiating at $100{ }^{\circ} \mathrm{C}$ and with an opening returntemperature of $350{ }^{\circ} \mathrm{C}$, was followed up to a maximum final temperature of $500{ }^{\circ} \mathrm{C}$. Temperature increments of $50{ }^{\circ} \mathrm{C}$ were set for the following return-temperatures (i.e., $350,400,450$, and $500^{\circ} \mathrm{C}$ ).

\section{Paleointensity determinations}

Absolute paleointensity determinations were accomplished employing two different methodologies. The first set of paleointensity experiments was performed with the multi-specimen (MS) technique proposed by Hoffman et al. (1989) as modified by Dekkers and Böhnel (2006). Protocols for fraction correction (FC) and domain-state correction (DSC)-proposed by Fabian and Leonhardt (2010) - were also included. Three different standard paleomagnetic cores per flow were used for these experiments. Each standard paleomagnetic core was cut into eight specimens, which were pressed into standarddimension cylindrical salt pellets and labeled from 1 to 8 (e.g., X001-C-1-X001-C-8), obtaining 144 specimens. The multi-specimen method was carried out at a temperature of $450{ }^{\circ} \mathrm{C}$-a temperature below the lowermost Curie temperature observed from $\mathrm{k}$-T curves but enough to create a pTRM. Experiments were performed using a TD48-SC furnace (ASC Scientific) with laboratory fields varying from 10 to $70 \mu \mathrm{T}$, and increments of $10 \mu \mathrm{T}$. The following measurement sequence was applied to the specimens subjected this methodology: (i) the natural remanent magnetization (NRM) of the different specimens were measured; (ii) six specimens were oriented so that their corresponding NRM directions lay parallel to the axis of the heating compartment and heated at $450{ }^{\circ} \mathrm{C}$ using the first laboratory field selected $(10 \mu \mathrm{T})$. After cooled down, their remanences were measured; (iii) specimens were set and heated as in the previous step but inverting the laboratory field direction. Then, their remanences were measured; (iv) specimens were reheated in zero field and cooled infield, and their remanences measured; (v) Step (ii) was repeated. Once finished this fivestep procedure, another set of six specimens was worked, using the next laboratory field $(20 \mu \mathrm{T})$ up to $70 \mu \mathrm{T}$.

All calculations (relative differences between pTRMs and NRMs) and corresponding correction factors were accomplished following Fabian and Leonhardt (2010).

The so-called 'IZZI' method (Tauxe and Staudigel 2004; Yu et al. 2004) was employed for the second set of paleointensity experiments, using one or two standard paleomagnetic cores per flow, which were previously cut, pressed into salt pellets and numbered consecutively (e.g., X014C-1-X014C-4). 32 specimens were treated using the following measurement sequence: (i) The NRM of the specimens was measured. (ii) The specimens were heated to temperature $T_{1}$ in a close to zero $(\sim 50 \mathrm{nT})$ magnetic field strength and then their remanences were measured. (iii) The specimens were heated again to temperature $T_{1}$, but this time in the presence of a magnetic field $(50.0 \pm 0.5 \mu \mathrm{T})$, and then their remanences were measured. (iv) The next heating step is performed at a temperature $T_{2}$ (with $T_{1}<T_{2}$ ) in the presence of a magnetic field. (v) The $T_{2}$ temperature step is repeated in the absence of a magnetic field. (vi) The temperature is increased further to a $T_{3}$ value, the samples were heated in the absence of a magnetic field. (vii) A pTRM check is performed from $T_{3}$ to $T_{1}$. (viii) The specimens are then reheated to $T_{3}$ in the presence of a magnetic field. (ix) A pTRM tail check is performed. (x) Steps (iv) to (ix) were repeated as often as necessary to cover the entire Curie temperature range of the ferromagnetic minerals present in specimens under analysis.

Although cooling rate $(\mathrm{CR})$ effects on volcanic rocks are not normally considered in most paleointensity experiments (Morales et al. 2006), we have decided to consider it at the end of this experiment. Cooling rate dependence on TRMs was studied using a modified procedure to the one outlined by Chauvin et al. (2000) (e.g., Morales et al. 2006). Finally, to account for non-ideal multidomain (MD) behavior, the curvature $\mathrm{k}$ of the individual Arai plots was estimated.

\section{Results}

\section{k-T curves}

Stepwise low-field susceptibility vs temperature $(\mathrm{k}-\mathrm{T})$ curves helped to evidence the temperature range at which mineral alteration took place. In the cases of Flow 1 and Flow 3, evident magneto-chemical alteration seems to start at moderate temperatures, between 350 and $400{ }^{\circ} \mathrm{C}$ (Fig. 4). On the contrary, alteration appears to start at higher temperatures $\left(400{ }^{\circ} \mathrm{C}\right.$ and $\left.450{ }^{\circ} \mathrm{C}\right)$ in the case of Flow 6. The analysis of the susceptibility curves was accomplished using the Cureval 8.0.2 software (Chadima and Hrouda 2012).

\section{Paleointensity determinations \\ Reassessment of the Thellier-Coe results from the previous study}

Different factors play significant roles in the reliability of a paleointensity determination-quality of the experimental conditions, the occurrence of alteration, and the presence of remanent magnetization carried by MD grains (Calvo-Rathert et al. 2016). On the other hand, several statistical parameters and different reliability criteria for paleointensity determinations have been proposed to take into account for these experimental situations (e.g., Selkin and Tauxe 2000; Kissel and Laj 


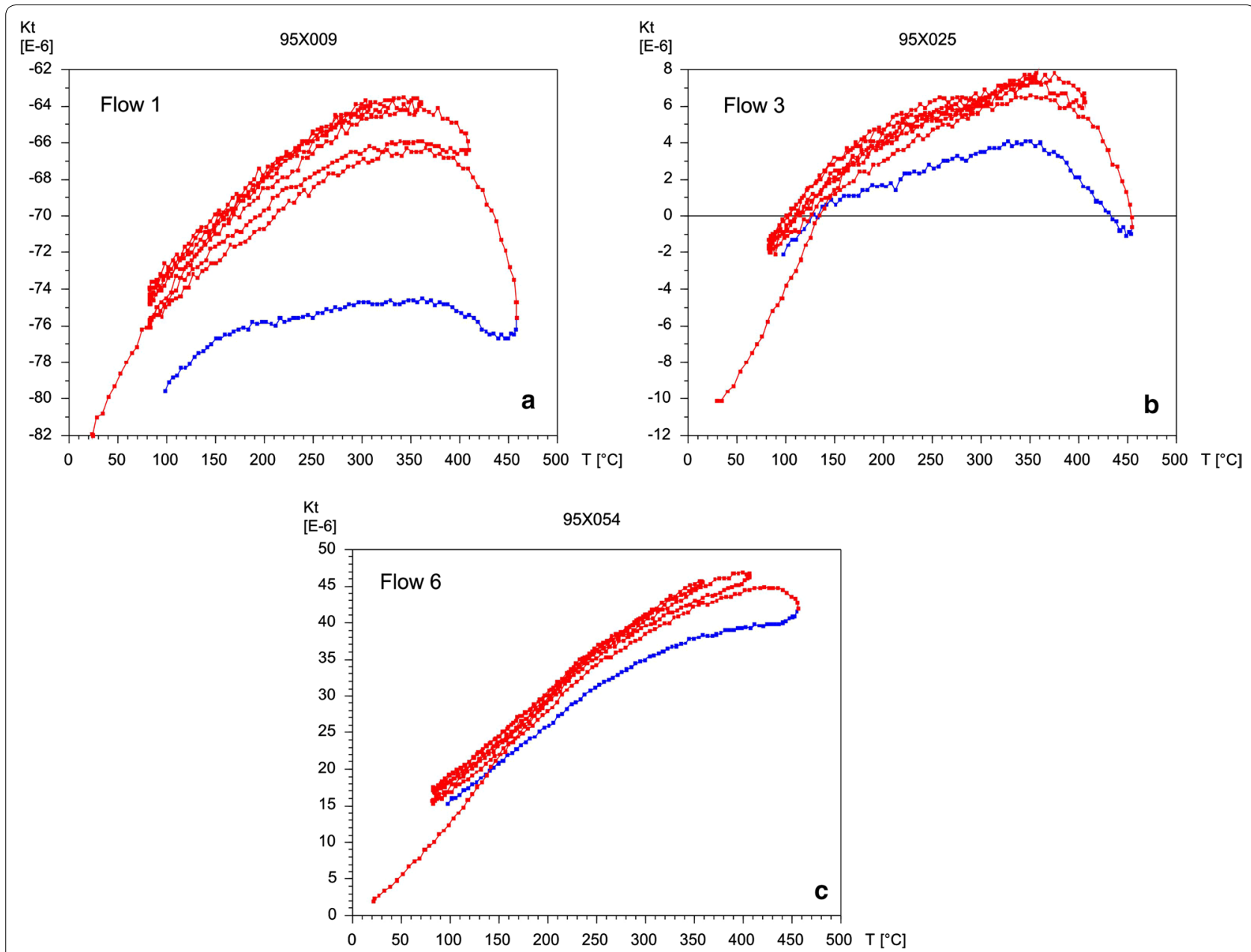

Fig. 4 Representative stepwise thermomagnetic $(k-T)$ curves for the different flows analyzed, obtained in this study. Peak heating steps used: 350 , 400,450 , and $500^{\circ} \mathrm{C}$. Curves in red correspond to the heating, while those in blue to the cooling

2004), however, no specific criteria and parameter set is normally applied (Calvo-Rathert et al. 2016).

Accordingly, we carried out a reassessment of the Thellier-Coe paleointensity results previously reported by Cervantes-Solano et al. (2019) on sister samples using the same stricter acceptance criteria used for the results obtained in this multi-methodological exercise.

Acceptance criteria of different strictness (A, B, or C, as proposed by Leonhardt et al. 2004) were employed to label successful paleointensity determinations according to specific quality levels, which are summarized in Table 1.

Additionally, concave-up shape Arai plots are rejected for the PI calculations because, in such cases, the remanence is very likely carried by MD grains (Levi 1977). Its contribution was assessed estimating the curvature $\mathrm{k}$ of the selected data points of the Arai plot (Paterson 2011). Following Paterson (2011), threshold values for $k=0.164$ and $k \leq 0.270$, defined using samples with known grain sizes, were used. The curvature $k$ was determined in MATLAB using the function CircleFitByPratt (XY) (Chernov 2019) which uses the method proposed by Pratt (1987) for fitting a circle to a set of data points on a plane. Estimation of paleointensity values was performed using the ThellierTool4.0 software (Leonhardt et al. 2004).

Based on the above-mentioned criteria, no reliable paleointensity determinations could be gathered from flows 1 and 2, except for one specimen from Flow 1 (X004A).

Most specimens showed very scattered Arai plots and negative pTRM checks even at low temperatures. Given the negative pTRM checks and the irreversible $\mathrm{k}$ - $\mathrm{T}$ behavior of the curves obtained on sister samples, this misbehavior could be attributed to significant thermochemical alteration during the paleointensity experiments. On the contrary, although with a very low success-rate, reliable PI determinations were obtained 
Table 1 Selection criteria and threshold values for the three determination classes (A, B, and C) for Thellier-Coe experiments

\begin{tabular}{llll}
\hline Class & $\boldsymbol{A}$ & $\boldsymbol{B}$ & $\boldsymbol{C}$ \\
\hline $\mathrm{N}$ & $\geq 5$ & $\geq 5$ & $\geq 5$ \\
$\sigma /$ slope & $\leq 0.10$ & $\leq 0.15$ & $\leq 0.15$ \\
$\mathrm{f}$ & $\geq 0.5$ & $\geq 0.3$ & $\geq 0.3$ \\
$\mathrm{q}$ & $\geq 3$ & $\geq 2$ & $\geq 2$ \\
MAD-anc & $\leq 5$ & $\leq 10$ & $\leq 10$ \\
$a$ & $\leq 15$ & $\leq 15$ & $\leq 15$ \\
$\delta(\mathrm{CK})$ & $\leq 5$ & $\leq 9$ & $\leq 15$ \\
$\delta($ pal) & $\leq 5$ & $\leq 10$ & $\leq 15$ \\
$\delta(\mathrm{TR})$ & $\leq 5$ & $\leq 7$ & $\leq 7$ \\
$\delta\left(t^{*}\right)$ & $\leq 3$ & $\leq 30$ & $\leq 30$ \\
\hline
\end{tabular}

$N$, number of points in the Arai plot used for the linear best-fit; $\sigma /$ slope, the ratio of the standard error of the slope of the selected segment in the Arai plot to the absolute value of the slope; $f$, NRM fraction used for the best-fit calculation; $q$ quality factor (Coe et al. 1978); MAD-anc, anchored maximum angular deviation; $a$, the angular difference between the anchored and non-anchored best-fit; $\delta(C K)$, relative check error; $\delta($ pal), cumulative check error (Leonhardt et al. 2004); $\delta(T R)$, relative intensity difference in pTRM tail check; $\delta\left(t^{*}\right)$ : the normalized tail of pTRM (Leonhardt et al. 2004)

from flows 3 to 6 . A representative Arai plot (Nagata et al. 1965b) is shown in Fig. 5a.

It is observed that flows 4 and 6 yielded slightly similar PI of $66.0 \pm 5.5 \mu \mathrm{T}(n=3)$ and $72.8 \pm 3 \mu \mathrm{T}(n=3)$, respectively. For flows 3 and 5 , however, only one specimen per flow yielded an acceptable result, 86.2 $\pm 4.0 \mu \mathrm{T}$, and $62.4 \pm 3.1 \mu \mathrm{T}$, respectively. Results are summarized in Table 2 and are graphically presented in Fig. 6.

This means that only 8 out of the 40 previously reported results $(20 \%)$ can be considered as reliable. If the curvature parameter is also considered, only five results survive $(12.5 \%)$.

Representative Arai (Nagata et al. 1965b) and associated vectorial (Zijderveld 1967) plots for the six flows analyzed are shown as Additional file 1: Figure S1.

\section{Multi-specimen method}

As above-mentioned, two magnetization components were observed in almost $60 \%$ of the samples studied. These soft overprints were also observed at the vectorial plots obtained from the Thellier-type double-heating method, which were eliminated at temperatures between 200 and $350{ }^{\circ} \mathrm{C}$. Thus, the chosen heating temperature of $450{ }^{\circ} \mathrm{C}$ seems to be suitable to remove these overprints on the one hand and locates somewhat below the Curie temperature observed from $\mathrm{M}-\mathrm{T}$ curves on the other hand, so that thermochemical alteration on the specimens due to heating should be less likely. Calculations were performed through the VBA software of Monster et al. (2015a).

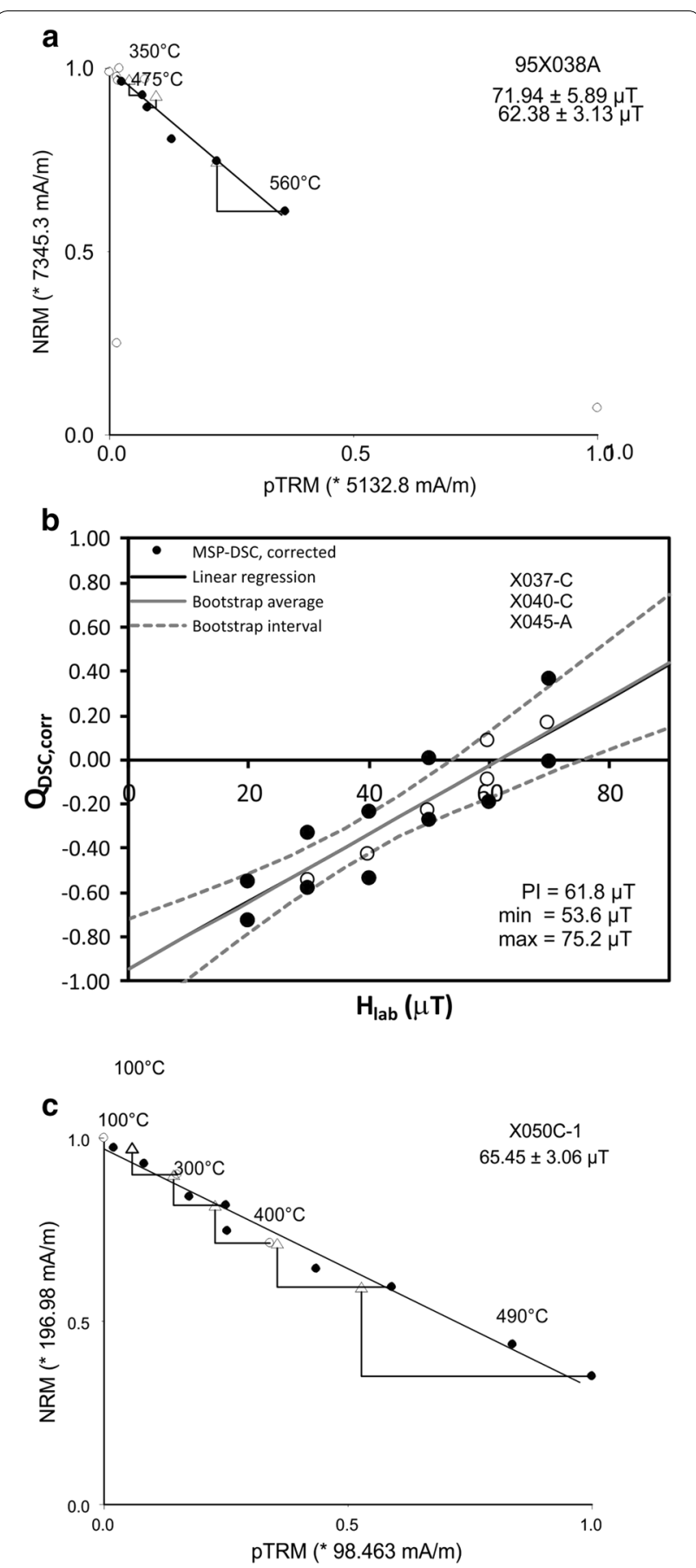

Fig. 5 a Representative Arai plot (Nagata et al. 1965b) obtained from the TC experiments. b Representative plot obtained from the MS experiments. c Representative Arai plot (Nagata et al. 1965b) obtained from the IZZI CRcorr experiments

Reliability criteria applied for this methodology was based on: (i) a maximum acceptable angular deviation (AAD) of $10^{\circ}$; (ii) the "overprint?" check and ( $\Delta$ dec and $\Delta$ inc) $<10^{\circ}$; (iii) the amount of progressive alteration 
Table 2 Thellier-Coe paleointensity results for all six studied flows. $T_{\min } / T_{\max }$ : lower/upper temperature step used to determine the archeointensity

\begin{tabular}{|c|c|c|c|c|c|c|c|c|c|c|c|c|c|c|c|c|c|c|}
\hline Name & $T_{\min }\left[{ }^{\circ} \mathrm{C}\right]$ & $\begin{array}{l}\mathrm{T}_{\max } \\
{\left[{ }^{\circ} \mathrm{C}\right]}\end{array}$ & $N$ & Slope & $\beta$ & $f$ & $g$ & $q$ & $M A D_{\text {anc }}$ & $a$ & Class & $\delta(\mathrm{CK})$ & $\delta($ pal) & $\delta\left(\mathrm{t}^{*}\right)$ & $\delta(\mathrm{TR})$ & $k$ & PI & $\sigma$ \\
\hline \multicolumn{19}{|l|}{ Flow 1} \\
\hline X004A & 20 & 540 & 10 & -1.4 & 0.1 & 0.8 & 0.8 & 10.1 & 1.1 & 1.0 & $C$ & 4.5 & 10.6 & 11.1 & 6.6 & & 62.4 & 4.1 \\
\hline \multicolumn{19}{|l|}{ Flow 3} \\
\hline $95 \times 017 A$ & 350 & 540 & 6 & -1.9 & 0.05 & 0.7 & 0.8 & 11.1 & 3.3 & 3.3 & C & 1.5 & 10.5 & 2.3 & 2.8 & 0.112 & 86.20 & 4.02 \\
\hline $95 \times 018 \mathrm{~A}$ & 350 & 540 & 6 & -1.8 & 0.07 & 0.4 & 0.7 & 4.2 & 2.3 & 4.2 & C & $\underline{32.8}$ & 1.7 & 1.9 & 2.0 & $\underline{0.470}$ & 80.00 & 5.77 \\
\hline \multirow[t]{2}{*}{$95 \times 019 A$} & 350 & 540 & 6 & -1.7 & 0.05 & 0.6 & 0.7 & 8.2 & 3.2 & 4.8 & C & $\underline{44.2}$ & $\underline{20.0}$ & 1.6 & 0.5 & $\underline{0.299}$ & 76.02 & 3.70 \\
\hline & & & & & & & & & & & & & & & & $\begin{array}{c}\text { Mean }= \\
\sigma=\end{array}$ & $\begin{array}{l}\text { N/A } \\
\text { N/A }\end{array}$ & \\
\hline \multicolumn{19}{|l|}{ Flow 4} \\
\hline $95 \times 022 \mathrm{~A}$ & 300 & 560 & 8 & -1.3 & 0.03 & 0.9 & 0.8 & 20.7 & 1.8 & 1.1 & B & 7.0 & 3.9 & 5.5 & 4.9 & 0.078 & 59.68 & 2.05 \\
\hline $95 \times 023 \mathrm{~A}$ & 20 & 450 & 7 & -1.5 & 0.06 & 0.5 & 0.6 & 5.2 & 1.8 & 2.5 & B & 1.7 & 5.8 & 0.6 & 0.0 & 0.190 & 69.49 & 4.06 \\
\hline $95 \times 024 A$ & 20 & 475 & 8 & -1.4 & 0.14 & 0.5 & 0.7 & 2.5 & 1.2 & 0.7 & B & 6.7 & 4.2 & 1.0 & 4.6 & $\underline{0.308}$ & 64.28 & 8.84 \\
\hline $95 \times 027 \mathrm{~A}$ & 300 & 560 & 8 & -1.5 & 0.05 & 0.5 & 0.8 & 8.7 & 1.7 & 2.2 & C & 10.3 & 3.8 & 2.9 & 2.1 & 0.008 & 68.74 & 3.25 \\
\hline \multirow[t]{2}{*}{$95 \times 028 \mathrm{~A}$} & 300 & 540 & 7 & -1.4 & 0.04 & 0.5 & 0.8 & 8.5 & 1.3 & 1.8 & C & $\underline{17.4}$ & $\underline{43.3}$ & 5.3 & 2.1 & 0.012 & 61.08 & 2.73 \\
\hline & & & & & & & & & & & & & & & & $\begin{array}{c}\text { Mean }= \\
\sigma=\end{array}$ & $\begin{array}{l}66.0 \\
5.5\end{array}$ & \\
\hline $95 \times 030 \mathrm{~A}$ & 300 & 560 & 8 & -1.4 & 0.05 & 0.5 & 0.8 & 7.7 & 1.1 & 1.3 & B & 1.9 & 8.9 & 1.9 & 2.7 & 0.108 & 62.38 & 3.13 \\
\hline \multirow[t]{2}{*}{$95 \times 033 \mathrm{~A}$} & 20 & 450 & 7 & -1.9 & 0.13 & 0.3 & 0.7 & $\underline{1.8}$ & 0.9 & 0.8 & B & 2.2 & 8.0 & 7.6 & 2.4 & 0.178 & 86.91 & 10.88 \\
\hline & & & & & & & & & & & & & & & & $\begin{array}{c}\text { Mean }= \\
\sigma=\end{array}$ & $\begin{array}{l}\text { N/A } \\
\text { N/A }\end{array}$ & \\
\hline \multicolumn{19}{|l|}{ Flow 6} \\
\hline $95 \times 036 \mathrm{~A}$ & 300 & 560 & 8 & -1.6 & 0.05 & 0.4 & 0.8 & 6.5 & 2.4 & 2.5 & $C$ & 12.6 & 12.4 & 1.5 & 1.9 & 0.186 & 70.25 & 3.33 \\
\hline $95 \times 037 A$ & 300 & 560 & 8 & -1.2 & 0.06 & 0.6 & 0.8 & 7.6 & 2.7 & 4.9 & C & 14.9 & 7.9 & 0.9 & 2.3 & $\underline{0.282}$ & 54.11 & 3.38 \\
\hline $95 \times 038 \mathrm{~A}$ & 200 & 560 & 9 & -1.6 & 0.08 & 0.4 & 0.7 & 3.4 & 1.0 & 0.6 & B & 3.8 & 3.8 & 0.0 & 1.8 & 0.167 & 71.94 & 5.89 \\
\hline $95 \times 039 A$ & 350 & 560 & 7 & -1.2 & 0.09 & 0.7 & 0.8 & 6.1 & 2.8 & 3.5 & C & $\underline{25.9}$ & $\underline{36.8}$ & 3.9 & 3.5 & $\underline{0.540}$ & 55.16 & 4.85 \\
\hline \multirow[t]{2}{*}{$95 \times 040 \mathrm{~A}$} & 100 & 450 & 6 & -1.7 & 0.11 & 0.3 & 0.7 & 2.1 & 0.7 & 1.0 & B & 0.6 & 0.3 & 3.3 & 1.8 & 0.037 & 76.15 & 8.00 \\
\hline & & & & & & & & & & & & & & & & $\begin{array}{c}\text { Mean }= \\
\sigma=\end{array}$ & $\begin{array}{l}72.8 \\
3.0\end{array}$ & \\
\hline
\end{tabular}

Terms from column 4 ("N") to column 16 (" $\delta(\mathrm{TR})$ ") as defined in Table 1. $k$ : curvature. $k=R^{-1}$, where R is the radius of the fitted circle to the data set (pTRM vs NRM); PI: paleointensity; $\sigma$ : standard deviation of paleointensity. Specimen names in italic face correspond to specimens rejected for the average intensity calculation because of exceeding of at least one of the threshold values (underlined) set for the corresponding assigned Class

$\left(\varepsilon_{\text {alt }}\right) \leq 10 \%$; (iv) the intersection with the $y$-axis $(\Delta \mathrm{b}=-1$ at $\left.\mathrm{H}_{\mathrm{lab}}=0\right)$, and $(v)$ the linear least-squares fit $\left(R^{2}\right)$.

All PI determinations fulfill with the criterion of $\delta \mathrm{b}$ between $(0,1)$ and show $r^{2}$ values $\geq 0.9$, except one case (Flow 5). However, despite the low enough chosen heating temperature of $450{ }^{\circ} \mathrm{C}$, Avg $\varepsilon_{\text {alt }}$ range between 6 and $12 \%$. In general, the original $\mathrm{DBc}$, fraction, and domainstate-corrected determinations with alignment correction (FCc and DSCc, respectively) yield higher $R^{2}$ values than the corresponding uncorrected values.

Flow 1 yielded a significantly lower mean PI value (21.6 $\mu \mathrm{T} ; \min =17.9 \mu \mathrm{T}, \max =23.8 \mu \mathrm{T})$, compared with those obtained from the other flows, and no significant differences between the results of the original $\mathrm{DBc}$ and the extended protocols FCc and DSCc are observed. Flow 2 and Flow 4 yielded undistinguishable PI values of $52.9 \mu \mathrm{T}$ and $49.5 \mu \mathrm{T}$, while Flow 3 and Flow 5 PI values of 58.2 $\mu \mathrm{T}$ and $61.8 \mu \mathrm{T}$, respectively. In the case of Flow 6, a PI value of $51.9 \mu \mathrm{T}$ was obtained, although with a higher Avg. $\varepsilon_{\text {alt }}$ of $-17.6 \%$. A summary of the results is provided in Table 3, and a representative plot is shown in Fig. 5b. Plots for the six flows analyzed are shown as Additional file 1: Figure S2.

\section{IZZI method}

For this type of experiment, a similar acceptance criterion to that used for the TC experiments was considered, and paleointensity estimations were performed also with the ThellierTool4.22 software (Leonhardt et al. 2004). No reliable results could be obtained from Flow 1 (specimens X003 and X007), except for one sub-specimen (X003C-2). Negative pTRM checks due to alteration, even at temperatures below $400{ }^{\circ} \mathrm{C}$, and a zig-zag type 


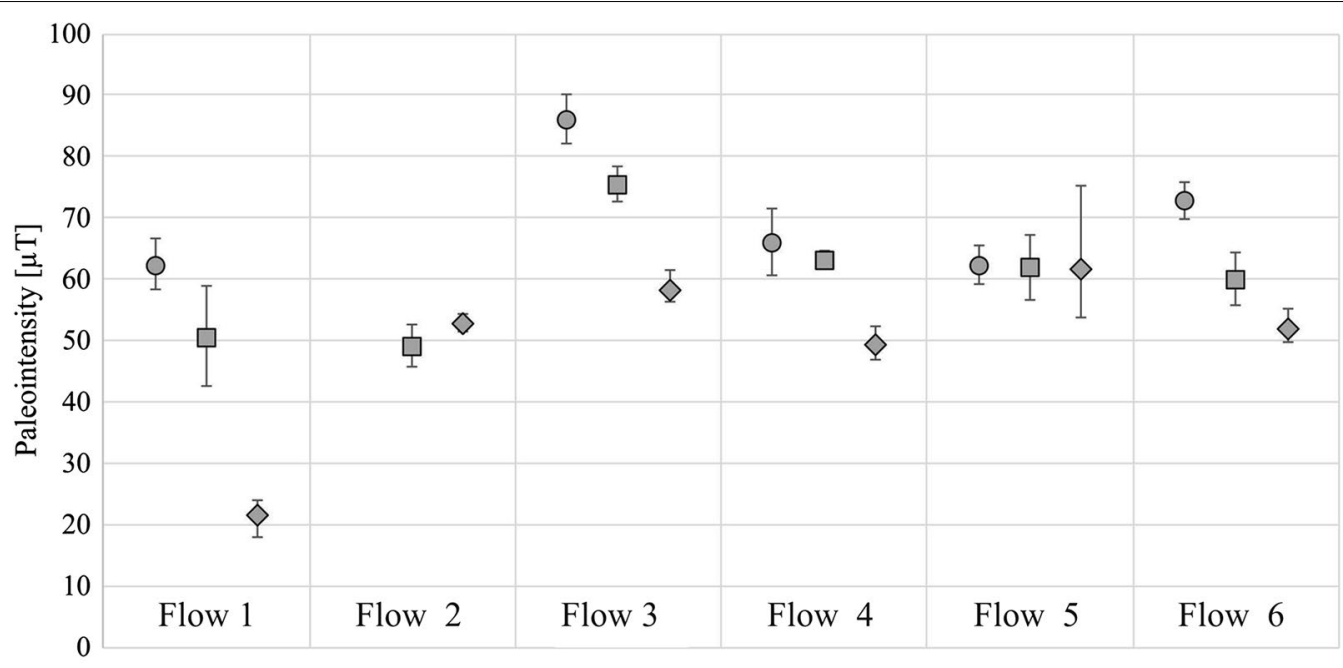

OTC $\square$ IZZI CR corr $\diamond$ MSP

Fig. 6 Comparison of PI results obtained by the different methodologies used (TC, IZZI CRcorr, and MS) for the 6 flows analyzed. Error bars represent the corresponding standard deviations in the case of TC and IZZI CRcorr results, while for the MS data to the Min and Max values obtained

Table 3 Multi-specimen $\left(Q_{\mathrm{DSC}}\right)$ paleointensity results for the different flows studied. Min and Max: estimated minimum and maximum paleointensity values

\begin{tabular}{|c|c|c|c|c|c|c|}
\hline Specimens flow & $\mathrm{PI}[\mu \mathrm{T}]$ & $\operatorname{Min}[\mu \mathrm{T}]$ & $\operatorname{Max}[\mu \mathrm{T}]$ & $\operatorname{Avg} \varepsilon_{\mathrm{alt}}[\%]$ & $\delta b$ & $r^{2}$ \\
\hline X001-C & 25.0 & 22.5 & 26.2 & 11.8 & -0.08 & 0.985 \\
\hline X005-C & 21.1 & 18.2 & 23.1 & 8.9 & 0.03 & 0.994 \\
\hline X009-C & 20.6 & 13.4 & 26.3 & 20.0 & -0.04 & 0.941 \\
\hline Flow 1 & 21.6 & 17.9 & 23.8 & 10.7 & 0.06 & 0.952 \\
\hline X0015-B & 73.4 & 71.3 & 78.0 & -3.2 & -0.02 & 0.983 \\
\hline X0017-B & 48.7 & 44.7 & 51.9 & -20.0 & -0.17 & 0.948 \\
\hline X0019-B & 52.9 & 51.5 & 54.2 & -12.4 & -0.03 & 0.995 \\
\hline Flow 2 & 52.9 & 51.4 & 54.3 & -12.4 & -0.03 & 0.995 \\
\hline X0020-B & 31.1 & 35.1 & 37.2 & -9.2 & 0.11 & 0.993 \\
\hline X0022-C & 58.2 & 56.5 & 61.1 & -6.1 & -0.02 & 0.986 \\
\hline X0026-C & 30.8 & 29.0 & 33.9 & -6.9 & 0.12 & 0.991 \\
\hline Flow 3 & 58.2 & 56.4 & 61.4 & -6.1 & -0.02 & 0.986 \\
\hline X0028-B & 31.7 & 28.8 & 36.9 & -9.0 & -0.48 & 0.932 \\
\hline X0033-C & 47.1 & 42.2 & 54.8 & -9.8 & 0.15 & 0.886 \\
\hline X0036-C & 49.7 & 48.4 & 50.6 & -13.3 & -0.07 & 0.997 \\
\hline Flow 4 & 49.5 & 46.8 & 52.3 & -11.0 & 0.04 & 0.954 \\
\hline X0037-C & 51.4 & 49.4 & 54.5 & -12.5 & 0.11 & 0.982 \\
\hline X0040-C & 71.9 & 69.2 & 76.6 & -9.1 & -0.03 & 0.974 \\
\hline X0045-A & 64.9 & & & -16.2 & -0.05 & 0.997 \\
\hline Flow 5 & 61.8 & 53.6 & 75.2 & -10.5 & 0.05 & 0.758 \\
\hline X0047-C & 36.4 & 34.8 & 39.9 & -14.9 & -0.23 & 0.979 \\
\hline X0049-C & 39.2 & 38.6 & 39.5 & -9.4 & -0.07 & 0.999 \\
\hline X0052-A & 52.2 & 49.8 & 54.7 & -18.6 & -0.07 & 0.986 \\
\hline Flow 6 & 51.9 & 49.6 & 55.1 & -17.6 & 0.00 & 0.974 \\
\hline
\end{tabular}

Reliability criteria: (i) the amount of progressive alteration $\varepsilon_{\text {alt }}$-a systematic (alteration-induced) error; (ii) the intersection with the $y$-axis $(-1<\delta \mathrm{b}<1)$ and (iii) $r^{2}$ : correlation coefficient of the linear regression. Data in italic represent the mean PI value calculated from the three specimens used in MS experiments 
behavior of the magnetization component observed at the Zijderveld plot precluded the estimation of PI values for this flow. One must note, however, that corresponding $\mathrm{k}-\mathrm{T}$ plot seems to be quite reversible up to a temperature of $\sim 450{ }^{\circ} \mathrm{C}$ (Fig. 3) and provided no clue for these unsuccessful results. Flow 2 (specimens X014 and X017) yielded consistent and quite reliable specimen's mean results of $49.4 \pm 4.4$ and $49.5 \pm 3.6 \mu \mathrm{T}$, respectively, with a flow mean result of $49.4 \pm 3.7 \mu \mathrm{T}(n=8)$. Flows 3 and 4 (specimens X029 and X032, respectively) yielded also consistent and quite reliable specimen's mean results of $76.5 \pm 3.2$ and $63.9 \pm 1.5 \mu \mathrm{T}$, respectively, although significantly higher than the underlying flow. For Flow 5 (specimens X041 and X042) two somewhat different specimen's mean results of $68.2 \pm 6.0$ and $59.4 \pm 3.6$ $\mu \mathrm{T}$, respectively, were obtained, with a flow mean result of $63.8 \pm 6.6 \mu \mathrm{T}(n=8)$. In case of Flow 6 (specimens X047 and X050) quite similar specimen's mean results of $63.9 \pm 10.2$ and $64.0 \pm 2.3 \mu \mathrm{T}$, respectively, with a flow mean result of $63.9 \pm 6.9 \mu \mathrm{T} \quad(n=8)$. A representative Arai plot (Nagata et al. 1965b) is shown in Fig. 5c. Results are summarized in Table 4 and are graphically presented in Fig. 6.

Representative examples of the Arai plots (Nagata et al. 1965b) for the six flows are shown as Additional file 1: Figure S3. The corresponding vectorial plots (Zijderveld 1967) are shown as Additional file 1: Figure S4.

From the different individual specimen's results from flows 4-6, an overall Xitle's PI value of $63.9 \pm 5.8 \mu \mathrm{T}$ $(n=20)$ was estimated. Corresponding cooling ratecorrected values yield an overall PI value of $61.5 \pm 4.3$ $\mu \mathrm{T}(n=19)$. As noted, the cooling rate correction of PI results slightly reduced the raw value and, in some cases, also the dispersion. Half of the 32 analyzed specimens showed $k$ values $<0.164$, seven $0.164<k<0.270$ and only one a $k>0.270$. Representative plots of the fitted circles to the data of the Arai diagrams are shown as Additional file 1: Figure S5.

\section{Discussion and concluding remarks}

The comparison between the results obtained by the three methods used (TC, IZZI CRcorr, and MS) shows some differences (Table 5). TC type results are in most cases higher than corresponding IZZI CRcorr values, except for Flow 5. On the contrary, MS data are in most cases significantly lower than the corresponding Thelliertype values, except for Flow 2 and Flow 5. For this last flow, a PI of $61.8 \mu \mathrm{T}$, compatible with those obtained from Thellier-type methods, was obtained. In general, the thermochemical alteration-attested by Avg $\varepsilon_{\text {alt }}>10 \%-$ seems to be the main cause for the inter-method differences observed.
Taking into account that consistent results obtained with methodologies relying on dissimilar physical bases can be regarded as an alternative means to support the reliability of paleointensity determinations (e.g., De Groot et al. 2015; Enterpinar et al. 2016; Monster et al. 2015b; Calvo-Rathert et al. 2016), similar results for Flow 5 obtained by the three methodologies should be considered as the most reliable PI value for this flow. A mean multi-method PI flow value of $62.1 \pm 5.9 \mu \mathrm{T}(n=12)$ was obtained for Flow 5.

The results obtained from the Thellier-type methodologies are very similar in the cases of Flow 4 and Flow 5, and slightly different in the case of Flow 6 (Fig. 6). Overall mean PI flow values from flows 4 to 6 obtained by the TC methods used yielded $68.4 \pm 5.6 \mu \mathrm{T}$ and $61.5 \pm 4.3 \mu \mathrm{T}$ for the TC and IZZI CRcorr methods, respectively. Therefore, the cooling rate-corrected IZZI result could be considered as the most reliable PI result for the flows 4-6 sequence of the Xitle.

As a support for the reliability of the obtained results, Alva-Valdivia et al. (2020) recently carried out a reassessment of paleointensity estimated of a single lava flow from Xitle volcano by means of the multispecimen domain-state-corrected method, obtaining nearly identical paleointensity results of $60.5 \pm 4 \mu \mathrm{T}$. Figure 7 shows a summary of the results obtained in this investigation, together with the results obtained in previous studies on lavas of the Xitle volcano. We must mention that previous studies on potteries or baked sediments found beneath Xitle's lavas were excluded since this would inevitably add another factor (anisotropy of thermoremanence) to be considered in the study.

At this point, a comparison of our results against the different model predictions available-CALS10k.1b (Constable et al. 2016), SHA.DIF.14 k (Pavón-Carrasco et al. 2014), A_FM (Licht et al. 2013), etc.-seems natural. Nonetheless, the different model predictions available show, for some intervals, significant differences.

On the other hand, even though the Xitle is one of the youngest volcanoes, a breadth age-interval for the Xitle's eruption does (still) persist, as mentioned above. Moreover, among the different age intervals proposed so far, that of Siebe (2000) and Gonzalez et al. (2000) (1670 BP) would seem to be the more reliable one. However, Urrutia-Fucugauchi et al. (2016) recently carried out a bootstrap analysis of radiocarbon dates and paleomagnetic data-by correlating full vector data with the geomagnetic secular variation reference model (SHA. DIF.14 k) -for the Xitle lava flows to constrain the best date estimates, from which new age estimates (2041 BP and $2035 \mathrm{BP}$, respectively) for the eruption were determined. Therefore, an attempt to correlate PI estimates 


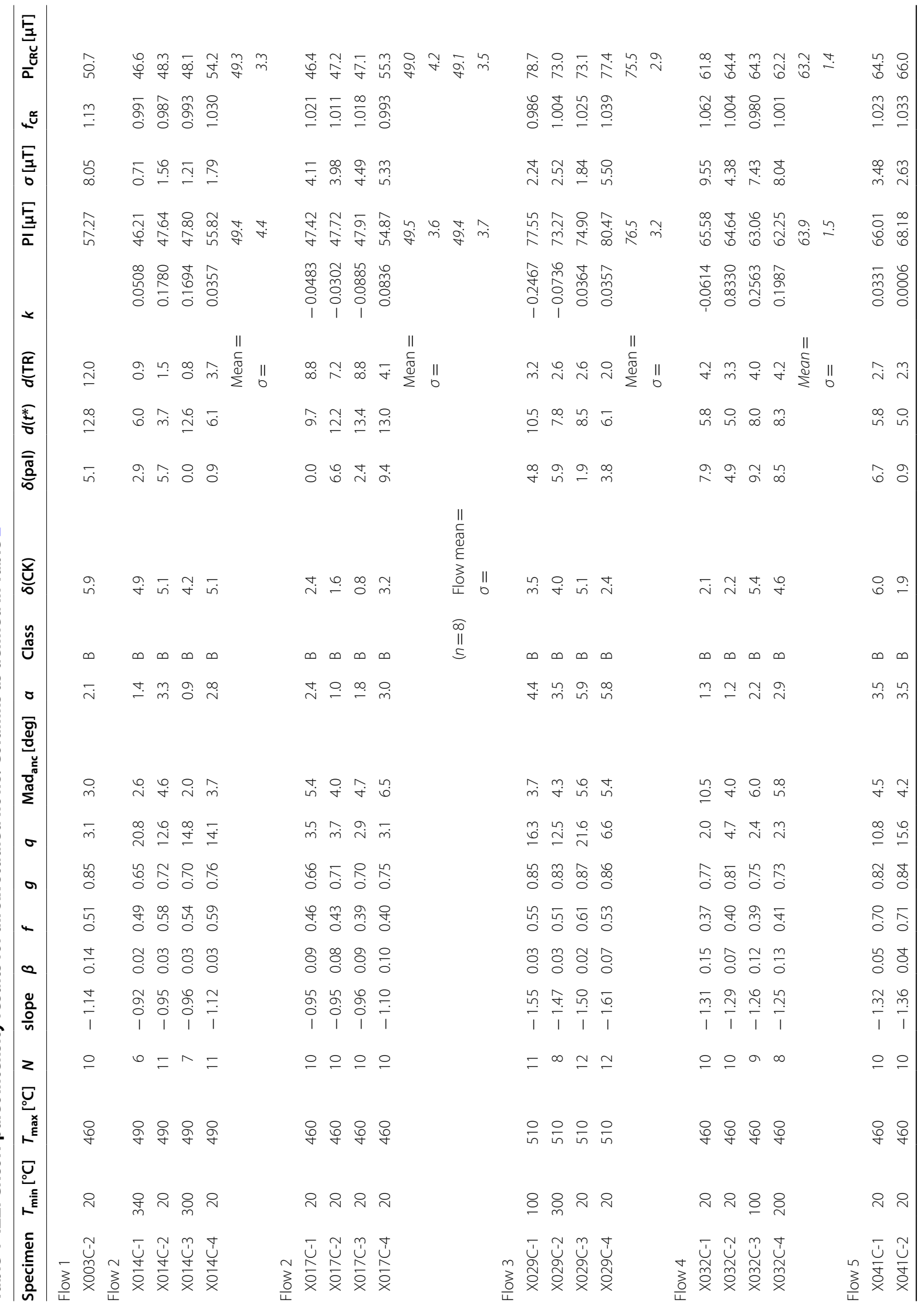




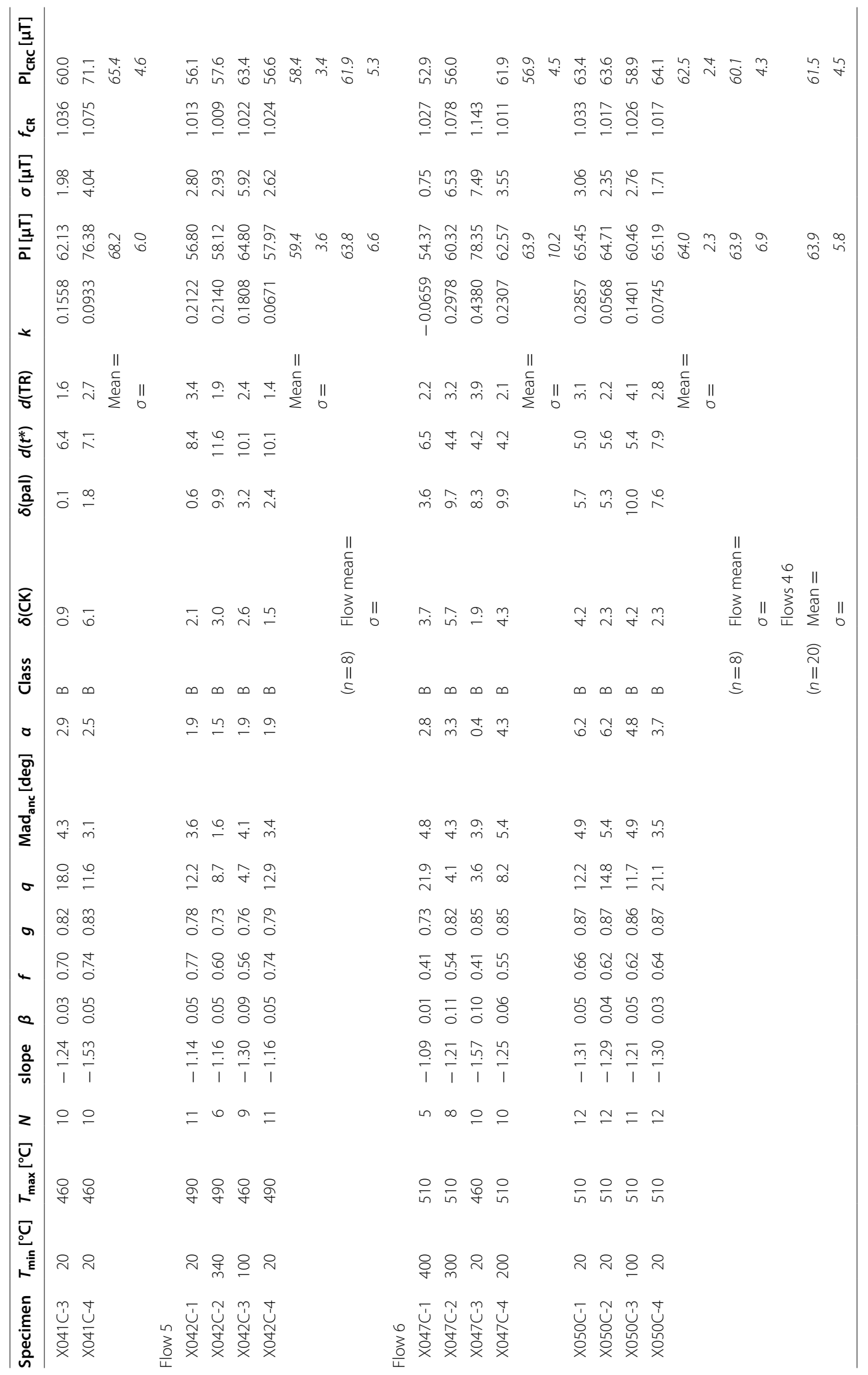


Table 5 Summary of the mean PI values from three methods for the six flows

\begin{tabular}{|c|c|c|c|c|c|c|c|c|c|}
\hline Flow & $\mathrm{TC}[\mu \mathrm{T}]$ & $\begin{array}{l} \pm \sigma \\
{[\mu \mathrm{T}]}\end{array}$ & $n$ & $\begin{array}{l}\text { IZZI CR } \\
{[\mu \mathrm{T}]}\end{array}$ & $\pm \sigma[\mu \mathrm{T}]$ & $n$ & $\mathrm{MS}[\mu \mathrm{T}]$ & $\operatorname{Min}[\mu \mathrm{T}]$ & $\operatorname{Max}[\mu \mathrm{T}]$ \\
\hline Flow 1 & 62.4 & 4.1 & 1 & 50.7 & 8.1 & 1 & 21.6 & 17.9 & 23.8 \\
\hline Flow 2 & $N / R$ & - & - & 49.1 & 3.5 & 8 & 52.9 & 51.4 & 54.3 \\
\hline Flow 3 & 86.2 & 4.0 & 1 & 75.5 & 2.9 & 4 & 58.2 & 56.4 & 61.4 \\
\hline Flow 4 & 66.0 & 5.5 & 3 & 63.2 & 1.4 & 4 & 49.5 & 46.8 & 52.3 \\
\hline Flow 5 & 62.4 & 3.1 & 1 & 61.9 & 5.3 & 8 & 61.8 & 53.6 & 75.2 \\
\hline Flow 6 & 72.8 & 3.0 & 3 & 60.1 & 4.3 & 7 & 51.9 & 49.6 & 55.1 \\
\hline
\end{tabular}

TC Thellier-Coe method, IZZI CRcorr IZZI method with cooling rate correction, MS multispecimen method, $n$ number of specimens used for PI calculation

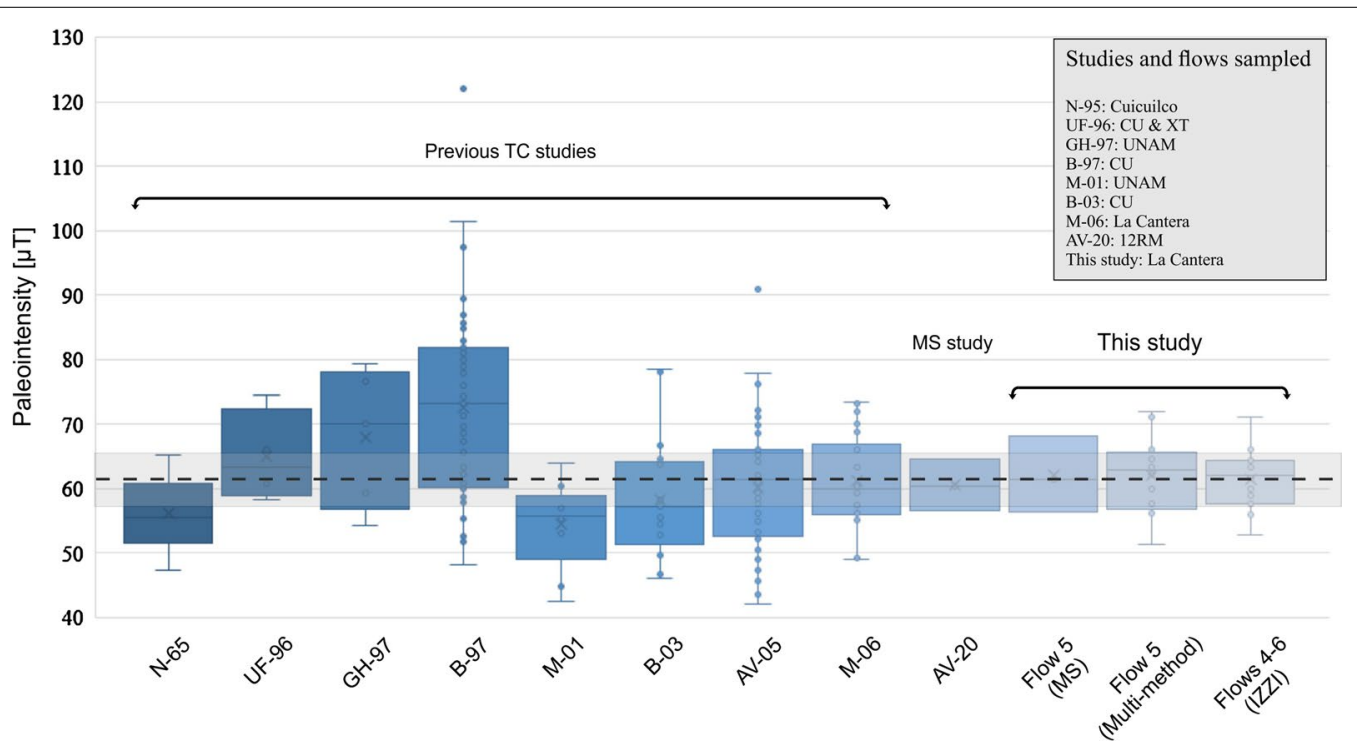

Fig. 7 Box-and-whisker plots showing the available lava PI data for Xitle, together with those obtained in this investigation. N-65: Nagata et al. (1965a); UF-96: Urrutia-Fucugauchi (1996); GH-97: Gonzalez et al. (1997); B-97: Böhnel et al. (1997); M-01: Morales et al. (2001); B-03: Böhnel et al. (2003); M-06: Morales et al. (2006); AV-20: Alva-Valdivia et al. (2020); Flow 5 (MS): mean Pl result for Flow 5 obtained with the MS method; Flow 5 (multi-method): mean PI result for Flow 5 obtained with the TC, IZZI CRcorr and MS methods; flows 4-6 (IZZI): mean PI result from flows 4-6 obtained with the IZZI CRcorr method. The dotted line and shaded area correspond to the Xitle's mean IZZI CRcorr paleointensity value obtained in this study, and its associated standard deviation

with the different model predictions would seem to be somewhat meaningless at this stage.

Another interesting result observed from Fig. 6 is that the IZZI CRcorr PI values for flows 1 and 2 are quite similar between them, but also quite different from those for flows 4-6. Cervantes-Solano et al. (2019) have suggested that this lava-flow sequence could represent, at least, two eruptive periods; one related to the Xitle volcano (flows 4-6), and other older (flows 1-2) of an unknown source. Nonetheless, Delgado-Granados et al. (1998) had already speculated the ages of the $\sim 4000 \mathrm{yr}$ cluster identified by Urrutia-Fucugauchi (1996) could represent the age of Tenantongo Basaltic Andesite, being geomorphologically very similar to Xitle volcano lavas, and thus, very easy to confuse.
Whether or not the mean paleodirections of flows 1 and 2 are statistically different from those of flows 3 to 6 is difficult to ascertain. However, a simple look at the corresponding equal-area projections suggests slightly different mean paleodirections (Fig. 8). Separated equalarea projections for flows 1 and 2 and for flows 3 to 6 are shown as Additional file 1: Figure S6.

The reassessment of the archeomagnetic dating of the different flows through the reference model SHA. DIF.14 k, using the reliable IZZI CRcorr PI data obtained in this study, yield the following periods as the most probable ages: [1620 BC-1520 BC] (3570 BP- $3470 \mathrm{BP}$ ) for Flow 1; [1749 BC-1597 BC] (3699 BP- $3547 \mathrm{BP}$ ) for Flow 2; [61 BC-5 BC] (2011 BP- 1955 BP) for Flow 3; [55 BC-1 AD] (2005 BP-1949 BP) for Flow 4; [24 BC-270 


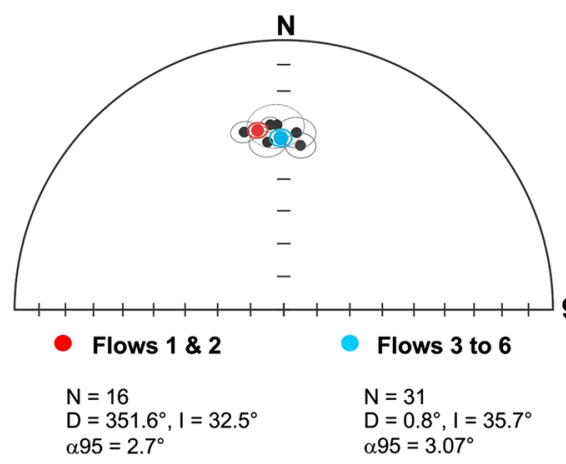

Fig. 8 Equal area projection showing the corresponding mean paleomagnetic directions for flows 1 and 2 (red dot), and for flows 3 to 6 (blue dot), together with their corresponding alpha_95 intervals

AD] (1974 BP-1680 BP) for Flow 5; [164 AD-342 AD] (1786 BP-1608 BP) for Flow 6, thus, supporting the different origin for the first two flows (Flow 1 and Flow 2) of the sequence on the one hand, and the multi-modal age distribution obtained by Urrutia-Fucugauchi (1996) on the other hand.

Dating of a burnt wood fragment found beneath a lava flow from Unit V yielded and age of $1960 \pm 65$ yr BP (Ortega-Guerrero et al. 1993), in good agreement with the archeomagnetic dating results. Archeomagnetic dating plots for the different flows are shown as Additional file 1: Figures S7.1-S7.6.

As evidenced from the results obtained, the large scatter of PI values obtained in previous studies should be attributed to the use of relaxed acceptance criteria on the one hand, and on the undetected non-ideal behavior-mainly $\mathrm{MD}$ effects and alteration during laboratory heating-on the other hand. This is comprehensible since those studies were carried out before stringent protocols-including extra experimental steps for the quantification and, when possible, the correction of non-ideal behavior (Paterson 2011) - were proposed, and due to the lack of standard tests.

From the results obtained in this investigation, the practice of stricter acceptance criteria, together with $C R$ correction and curvature estimation, would help to eliminate the "enigmatic" character to the Xitle's lava flows.

\section{Supplementary information}

Supplementary information accompanies this paper at https://doi. org/10.1186/s40623-020-01232-z.

Additional file 1. Additional figures.

\section{Abbreviations}

AAD: Acceptable angular deviation; AV-05: Alva-Valdivia et al. (2005); AV-20: Alva-Valdivia et al. (2020); Avg: Average; B-03: Böhnel et al. (2003); B-97:
Böhnel et al. (1997); BP: Before present; BCU: Ciudad Universitaria Basaltic Lava member; CRcorr: Cooling rate correction; DRAT: Difference ratio; DB: DekkersBöhnel method; DSC: Domain state correction; Flow 5 (MS): Mean PI result for Flow 5 obtained with the MS method; Flow 5 (Multi-method): Mean PI result for Flow 5 obtained with the TC, IZZI CRcorr and MS methods; Flows 4-6 (IZZI): Mean PI result from flows 4-6 obtained with the IZZI CRcorr method; FC: Fraction correction; GH-97: Gonzalez et al. (1997); IZZI: Infield, Zero field, Zero field, Infield paleointensity method; M-01: Morales et al. (2001); M-06: Morales et al. (2006); MAD-anc: Anchored maximum angular deviation; Max: Maximum; MD: Multidomain grains; Min: Minimum; MS: Multi-specimen method for paleointensity determinations; N-65: Nagata et al. (1965a); NRM: Natural remanent magnetization; PI: Paleointensity; PIcrc: Cooling rate-corrected PI; pTRM: Partial thermoremanent magnetization; TC: Thellier-Coe method; TRM: Thermoremanent magnetization; UF-96: Urrutia-Fucugauchi (1996); UNAM: Universidad Nacional Autónoma de México; VBA: Visual Basic for Applications.

\section{Acknowledgements}

We thank the editor and two anonymous reviewers for their exhaustive reading of the manuscript and their wise suggestions. NP appreciates the economic support of CONACYT for the Ph.D. program fellowship.

\section{Authors' contributions}

All authors contributed to the study conception and design. Fieldwork and paleomagnetic determinations were done by Miguel Cervantes-Solano. Material preparation, data collection, and analysis were performed by NP-R. The first draft of the manuscript was written by Juan Morales and all authors commented on previous versions of the manuscript. All authors read and approved the final manuscript.

\section{Funding}

AG acknowledges the financial support of CONACyT 252149 and UNAMPAPIIT projects IN105214 and 1N101920.

\section{Availability of data and materials}

The datasets used and/or analyzed during the current study are available from the corresponding author on reasonable request.

\section{Ethics approval and consent to participate}

Not applicable

\section{Consent for publication}

Not applicable.

\section{Competing interests}

The authors declare that they have no competing interests.

\section{Author details}

${ }^{1}$ Laboratorio Interinstitucional de Magnetismo Natural (LIMNA) y Servicio Arqueomagnético Nacional (SAN), Instituto de Geofísica, UNAM, Unidad Michoacán, Morelia, Mexico. ${ }^{2}$ Posgrado en Ciencias de la Tierra, UNAM, Unidad Michoacán, Campus Morelia, Morelia, Mexico. ${ }^{3}$ Escuela Nacional de Estudios Superiores Unidad Morelia, UNAM, Morelia, Michoacán, Mexico.

Received: 18 February 2020 Accepted: 8 July 2020

Published online: 13 July 2020

\section{References}

Alva-Valdivia LM (2005) Comprehensive paleomagnetic study of a succession of Holocene olivine-basalt flow: Xitle Volcano (Mexico) revisited. Earth Planets Space 57:839-853. https://doi.org/10.1186/BF03351862

Alva-Valdivia LM, Bravo-Ayala MA, Camps P, Poidras T, Mahgoub AN (2020) Reassessment of paleointensity estimated of a single lava flow from Xitle volcano, Mexico, by means of multispecimen domain-state corrected. J S Am Earth Sci 100:102549

Arnold JT, Libby WF (1951) Radiocarbon dates. Science 113:111-120

Böhnel H, Morales J, Caballero C, Alva L, McIntosh G, Gonzalez S, Sherwood G (1997) Variation of rock magnetic parameters and paleointensities over a single Holocene lava flow. J Geomag Geoelectr 49:523-542. https://doi. org/10.5636/jgg.49.523 
Böhnel H, Biggin AJ, Walton D, Shaw J, Share JA (2003) Microwave palaeointensities from a recent Mexican lava flow, baked sediments and reheated pottery. Earth Planet Sci Lett 214:221-236

Bullard FM (1976) Volcanoes of the Earth. University of Queensland Press, Saint Lucia

Calvo-Rathert M, Morales-Contreras J, Carrancho A, Goguitchaichvili A (2016) A comparison of Thellier-type and multispecimen paleointensity determinations on Pleistocene and historical lava flows from Lanzarote (Canary Islands, Spain). Geochem Geophys Geosyst 17:3638-3654. https://doi. org/10.1002/2016GC006396

Calvo-Rathert M, Morales-Contreras J, Carrancho A, Camps P, Goguitchaichvili A (2019) Reproducibility of archaeointensity determinations with a multimethod approach on archaeological material reproductions. Geophys J Int 218(3):1719-1738. https://doi.org/10.1093/gji/ggz246

Cervantes-Solano M, Cifuentes-Nava G, Caballero-Miranda Cl, Goguitchaichvili A, López-Loera H, Delgado-Granados H, Morales-Contreras J, UrrutiaFucugauchi J (2019) Estudio magnético integral de flujos de lava del volcán Xitle: implicaciones arqueológicas sobre el abandono de Cuicuilco. Bol Soc Geol Mex 71(2):397-411

Chadima, M., Hrouda, F. (2012) Cureval 8.0.2: Thermomagnetic Curve Analyser for Windows. Agico, Inc

Chauvin A, Garcia Y, Lanos P, Laubenheimer F (2000) Paleointensity of the geomagnetic field recovered on archaeomagnetic sites from France. Phys Earth Planet Int 120:111-136. https://doi.org/10.1016/S0031 $-9201(00) 00148-5$

Chernov N (2019) Circle Fit (Pratt method) (https://www.mathworks.com/ matlabcentral/fileexchange/22643-circle-fit-pratt-method), MATLAB Central File Exchange. Retrieved December 31, 2019

Coe RS (1967) The determination of paleointensities of the Earth's magnetic field with emphasis on mechanisms which could cause non-ideal behavior in Thellier's method. J Geomagn Geoelectr 19(3):157-179. https://doi. org/10.5636/jgg.19.157

Coe RS, Grommé S, Mankinen EA (1978) Geomagnetic paleointensities from radiocarbon dated lava flows on Hawaii and the question of the Pacific nondipole low. J Geophys Res 83(B4):1740-1756. https://doi.org/10.1029/ JB083iB04p01740

Constable C, Korte M, Panovska S (2016) Persistent high paleosecular variation activity in southern hemisphere for at least 10000 years. Earth Planet Sci Lett 453:78-86. https://doi.org/10.1016/j.epsl.2016.08.015

De Groot LV, Béguin A, Kosters ME, Van Rijsingen EM, Struijk ELM, Biggin AJ, Hurst EA, Langereis CG, Dekkers MJ (2015) High paleointensities for the Canary Islands constrain the Levant geomagnetic high. Earth Planet Sci Lett 419:154-167. https://doi.org/10.1016/jepsl.2015.03.020

Dekkers MJ, Böhnel HN (2006) Reliable absolute palointensities independent of magnetic domain state. Earth Planet Sci Lett 248:508-517. https://doi. org/10.1016/j.epsl.2006.05.040

Delgado-Granados H, Molinero R, Cervantes P, Nieto-Obregón J, Lozano-Santa Cruz R, Macías-González HL, Méndoza-Rosales C, Silva-Romo G (1998) Geology of Xitle volcano in southern Mexico City -A 2000-year-old monogenetic volcano in an urban área. Revista Mexicana de Ciencias Geológicas 15(2):115-131

Enterpinar P, Langereis CG, Biggin AJ, de Groot LV, Kulakoglu F, Osmura S, Süel A (2016) Full vector archaeomagnetic records from Anatolia between 2400 and 1350 BCE: implications for geomagnetic field models and the dating of fires in antiquity. Earth Planet Sci Lett 434:171-186. https://doi. org/10.1016/j.epsl.2015.11.015

Fabian K, Leonhardt R (2010) Multiple-specimen absolute paleointensity determination: an optimal protocol including PTRM normalization, domainstate correction, and alteration test. Earth Planet Sci Lett 297:84-94. https ://doi.org/10.1016/j.epsl.2010.06.006

Fergusson GS, Libby WF (1963) UCLA radiocarbon dates 11. Radiocarbon $5: 1-22$

Gonzalez S, Sherwood GJ, Böhnel H, Schnepp E (1997) Paleosecular variation in central Mexico over the last 30,000 years: the record from lavas. Geophys J Int 130:201-219

Gonzalez, S., Pastrana A., Siebe, C., Duller, G. (2000) Timing of the prehistoric eruption of Xitle Volcano and the abandonment of Cuicuilco Pyramid, Southern Basin of Mexico. Geological Society, London, Special Publications (Geol. Soc. London Sp. Pub.) 171: 205-224
González-Huesca IS (1992) La variación secular en México central durante los últimos 30,000 años por medio del estudio magnético de lavas. Doctoral Thesis, National University of Mexico, Mexico City

Heizer RF, Bennyhoff JA (1958) Archeological investigations of Cuicuilco, Valley of Mexico, 1957. Science 127(3292):232-233. https://doi.org/10.1126/ science.127.3292.232

Herrero-Bervera E, Urrutia-Fucugauchi J, Martin-del Pozzo AL, Böhnel H, Guerrero J (1986) Normal amplitude Brunhes paleosecular variation at low latitudes: a paleomagnetic record from the Trans-Mexican Volcanic Belt. Geophys Res Lett 13(13):1442-1445. https://doi.org/10.1029/GL013i013p 01442

Hoffman KA, Constantine VL, Morse DL (1989) Determination of absolute palaeointensity using a multi-specimen procedure. Nature 339:295-297

Kissel C, Laj C (2004) Improvements in procedure and paleointensity selection criteria (PICRIT-03) for Thellier and Thellier determinations: application to Hawaiian basaltic long cores. Phys Earth Planet Inter 147:155-169. https ://doi.org/10.1016/j.pepi.2004.06.010

Leonhardt R, Heunem C, Krása D (2004) Analyzing absolute paleointensity determinations: acceptance criteria and the software Thellier Tool4.0. Geochem Geophys Geosyst 5:12. https://doi.org/10.1029/2004GC000807

Levi S (1977) The effect of magnetite particle size on paleointensity determinations of the geomagnetic field. Phys Earth Planet Inter 13:245-259. https ://doi.org/10.1016/0031-9201(77)90107-8

Libby WF (1955) Radiocarbon Dating, 2nd edn. Chicago University Press, Chicago

Licht A, Hulot G, Gallet Y, Thébault (2013) Ensembles of low degree archeomagnetic field models for the past three millennia. Phys Earth Planet Inter 224:38-67

Martin-Del Pozzo AL, Cordoba C, López J (1997) Volcanic impact on the southern Basin of Mexico during the Holocene. Quatern Int 43-44:181-190. https://doi.org/10.1016/S1040-6182(97)00034-7

Monster MWL, de Groot LV, Dekkers MJ (2015a) MSP-Tool: a VBA-based software tool for the analysis of multispecimen paleointensity data. Front Earth Sci 3:86. https://doi.org/10.3389/feart.2015.00086

Monster MWL, de Groot LV, Biggin AJ, Dekkers MJ (2015b) The performance of various palaeointensity techniques as a function of rock-magnetic behaviour - a case study for La Palma. Phys Earth Planet Inter 242:36-49. https://doi.org/10.1016/j.pepi.2015.03.004

Morales J, Goguitchaichvili A, Urrutia-Fucugauchi J (2001) A rock-magnetic and paleointensity study of some Mexican volcanic lava flows during the Latest Pleistocene to the Holocene. Earth Planets Space. 53(9):893-902

Morales J, Alva-Valdivia LM, Goguitchaichvili A, Urrutia-Fucugauchi J (2006) Cooling Rate Corrected Paleointensities From the Xitle Lava Flow: evaluation of Within-Site Scatter for Single Spot-Reading Cooling Units. Earth Planets Space 58(10):1341-1347. https://doi.org/10.1186/BF03352630

Morales-Contreras JJ (1995) Determinación de paleointensidades del campo geomagnético para el Cuaternario en la Sierra Chichinautzin, Ms.SC. Thesis, UNAM, México

Nagata T, Kobayashi K, Schwarz EJ (1965a) Archeomagnetic intensity studies of South and Central America. J Geomagn Geoelectr 17:399-405. https:// doi.org/10.5636/jgg.17.399

Nagata T, Arai Y, Momose K (1965b) Secular variation of the geomagnetic total force during the last 5000 years. J Geophys Res 68:5277-5282

Ortega-Guerrero B, Urrutia-Fucugauchi J, Nieto-Obregón J (1993) Geología y edades C-14 del derrame del Pedregal de San Ángel: México City. Universidad Nacional Autónoma de México, Instituto de Geofísica, Internal report (unpublished)

Paterson G (2011) A simple test for the presence of multidomain behavior during paleointensity experiments. J Geophys Res 116:10104. https://doi. org/10.1029/2011jb008369

Pavón-Carrasco FJ, Osete ML, Torta JM, De Santis A (2014) A geomagnetic field model for the Holocene based on archaeomagnetic and lava flow data. Earth Planet Sci Lett 388:98-109

Pratt V (1987) Direct least-squares fitting of algebraic surfaces. Computer Graphics 21(4):145-152. https://doi.org/10.1145/37402.37420

Selkin PA, Tauxe L (2000) Long-term variations in paleointensity. Phil Trans R Soc A 358:1065-1088. https://doi.org/10.1098/rsta.2000.0574

Siebe C (2000) Age and archaeological implications of Xitle volcano, southwestern Basin of Mexico-City. J Volcanol Geoth Res 104:45-64. https://doi. org/10.1016/S0377-0273(00)00199-2 
Tauxe L, Staudigel H (2004) Strength of the geomagnetic field in the Cretaceous Normal Superchron: new data from submarine basaltic glass of the Troodos Ophiolite. Geochem Geophys Geosistems 5:2. https://doi. org/10.1029/2003gc000635

Thellier E, Thellier O (1959) Sur l'intensite' du champ magnétique terrestre dans le passé historique et géologique. Ann Geophys 15:285-376

Urrutia-Fucugauchi J (1996) Paleomagnetic study of the Xitle-Pedregal de San Angel lava flow, southern basin of Mexico. Phys. Earth Planet. Int. 97:177-196

Urrutia-Fucugauchi J, Martin-del Pozzo AL (1993) Implicaciones de los datos paleomagnéticos sobre la edad de la Sierra de Chichinautzin, Cuenca de México. Geofísica Internacional 32:523-533

Urrutia-Fucugauchi J, Goguitchaichvili A, Pérez-Cruz L, Morales J (2016) Archaeomagnetic dating of the eruption of the Xitle volcano, basin of
Mexico: Implications for the Mesoamerican Centers of Cuicuilco and Theotihuacan, Arqueología Iberoamericana 30: 23-29. http://laiesken. net/arqueologia/archivo/2016/30/4

Yu Y, Tauxe L, Genevey A (2004) Toward an optimal geomagnetic field intensity determination technique. Geochem Geophys Geosistems. https:/doi. org/10.1029/2003GC000630

Zijderveld JDA (1967) AC demagnetization of rocks: analysis of results. In: Collinson D, Creer KM, Runcorn SK, eds. Methods in paleomagnetism, 3 , $254-286$

\section{Publisher's Note}

Springer Nature remains neutral with regard to jurisdictional claims in published maps and institutional affiliations.

\section{Submit your manuscript to a SpringerOpen ${ }^{\circ}$ journal and benefit from:}

- Convenient online submission

- Rigorous peer review

- Open access: articles freely available online

- High visibility within the field

- Retaining the copyright to your article

Submit your next manuscript at $\boldsymbol{\nabla}$ springeropen.com 